Jakub Parol

\title{
Działalność Mikołaja z Kutna na Mazowszu w początkach jego kariery politycznej
}

W latach 1454-1466 Królestwo Polskie uwikłane było w wojnę trzynastoletnią. W tym także czasie, a konkretnie w roku 1462, do Korony wcielono ziemie rawską i gostynińską. Mikołaj z Kutna brał udział w obu tych wydarzeniach: w wojnie trzynastoletniej - jako poddany książąt zachodniego Mazowsza, a w trakcie przyłączenia ziemi gostynińskiej - jako stronnik króla Kazimierza Jagiellończyka (choć początek jego kariery politycznej był związany z Księstwem Mazowieckim).

W swoim artykule skoncentruję się na latach 1430-1462, obejmujących czas od urodzenia Mikołaja do wystawienia przez króla dokumentu o wcieleniu ziemi gostynińskiej do Korony.

Najpierw chciałbym krótko przedstawić biografię bohatera niniejszego przyczynku. Data jego urodzin jest nieznana, jednak większość badaczy przyjmuje, że urodził się ok. 1430 r. ${ }^{1}$ Ryszard Rosin, w monografii Kutna, zdecydował się przesunąć datę urodzin Mikołaja przed tym rokiem². Mikołaj był synem Jana z Kutna h. Ogończyk i nieznanej z imienia matki. Jan był podkomorzym, stolnikiem, a następnie kasztelanem gostynińskim. Z kolei Mikołaj z Kutna, po wcieleniu ziemi gostynińskiej i rawskiej do Korony, sprawował kolejno urzędy wojewody rawskiego, wojewody łęczyckiego i starosty generalnego wielkopolskiego. Należał do grona osób, które odprowadzały królewicza Władysława, syna Kazimierza Jagiellończyka, na tron czeski. W trakcie walki z Mikołajem Tungenem występował jako poseł królewski na stany pruskie, a podczas starć z Maciejem Korwinem w 1474 r., pod Wrocławiem, prowadził z nim rokowania w celu zawarcia rozejmu. Towarzyszył także córkom Kazimierza Jagiellończyka w podróży do miejsc zawarcia ich ślubów. Zmarł w 1493 r. $^{3}$ Mikołaj z Kutna miał pięcioro

1 A. Gąsiorowski, Kucieński Mikołaj, [w:] Polski słownik biograficzny, t. 16, red. E. Rostowski, Wrocław-Warszawa-Kraków 1971, s. 63.

2 R. Rosin, Kutno i okoliczne miejscowości do połowy XVI w., [w:] Kutno - dzieje miasta, red. R. Rosin, Warszawa-Łódź 1984, s. 29.

3 A. Gąsiorowski, Kucieński Mikołaj, s. 63-64. 
rodzeństwa: Andrzeja, Jakuba, Jadwigę, Barbarę i Elżbietę. Jednak synowie Jana pochodzili prawdopodobnie z jego pierwszego małżeństwa, córki natomiast $\mathrm{z}$ drugiego ${ }^{4}$.

Niestety, nie znamy dzieciństwa Mikołaja. Możemy jedynie stwierdzić, że jego ojciec, który był blisko związany z dworem książęcym, dość szybko umieścił tam także swojego syna. W roku 1448 występuje bowiem w dokumencie Włodzisława I płockiego ${ }^{5}$, datowanym na 31 października, w Busku. Włodzisław I transumował wówczas dokument swojego ojca Siemowita z 1411 r., zezwalający mieszkańcom Buska na pobieranie z położonych w pobliżu lasów drewna oraz siana. W dokumencie oprócz wspomnianego Mikołaja wymienieni zostali także Świętosław Golasz z Łęga, Krzysztof z Kępy oraz Szymon Bylina z Leszczyn ${ }^{6}$. Według Kazimierza Pacuskiego, Mikołaj towarzyszył wtedy księciu w jego podróży do ziemi bełskiej ${ }^{7}$.

Prawdopodobnie około roku 1453 nasz bohater ożenił się z Barbarą z Miłonic, z ziemi łęczyckiej ${ }^{8}$. Należy stwierdzić, że istniały kontakty pomiędzy szlachtą ziemi łęczyckiej a Kucieńskimi. Ojciec Mikołaja otrzymał od swojej drugiej żony, Małgorzaty z Krzyżanowa i Szydłowa, trzecią część dóbr w Krzyżanowie, Szydłowie i Woli Szydłowskiej, znajdujących się w ziemi łęczyckiej9.

W przypadku Mikołaja problem rodzi się przy okazji uzyskania pierwszego urzędu - z jednej strony występował on w roku $1455 \mathrm{r}$. jako podczaszy gostyniński, a od 1459 r. jako podstoli gostyniński. K. Pacuski uważał, że był to błąd popełniony przez osobę, która sporządziła dokument. Około $1461 \mathrm{r}$. obejmuje starostwo gostynińskie i urząd tamtejszego stolnika ${ }^{10}$.

4 T. Nowak, Kutno i Łąkoszyn do schyłku XVI wieku, [w:] Kutno poprzez wieki, red. J. Szymczak, Łódź-Kutno 2011, s. 137.

5 Włodzisław I (1406/10-1455) był najmłodszym synem Siemowita IV i Aleksandry Olgierdówny, a jego żoną była Anna, córka księcia Oleśnickiego Konrada V. Włodzisław I władał ziemią płocką, wiską, zawkrzeńską, płońską i rawską - J. Grabowski, Dynastia Piastów Mazowieckich. Studia nad dziejami politycznymi Mazowsza, intytulacją i genealogia książąt, Kraków 2012, s. 331-332, 467.

6 Zbiór dokumentów małopolskich, cz. 8, red. I. Sułkowska-Kuraś, S. Kuraś, Wrocław 1975, s. 327-328, dok. 2018.

7 K. Pacuski, Możnowładztwo i rycerstwo ziemi gostynińskiej w XIV i XV w. Studium z dziejów osadnictwa i elity władzy na Mazowszu średniowiecznym, Warszawa 2009, s. 165.

8 Ibidem.

9 T. Nowak, Własność ziemska w ziemi łęczyckiej w czasach Władysława Jagiełły, Łódź 2003, s. 230.

10 K. Pacuski, Możnowładztwo..., s. 165. 
Najprawdopodobniej przed rokiem 1455 r. nie piastował żadnego urzędu. Sugeruje to dokument książęcy z 1454 r. dotyczący zrzeczenia się przez siostrę Mikołaja, Jadwigę, swoich dóbr na rzecz Mikołaja właśnie i jego brata Andrzeja, którzy w tekście zostali wymienieni bez żadnego urzędu ${ }^{11}$.

W 1461 r., podczas wojny trzynastoletniej, Mikołaj dowodził posiłkami mazowieckimi, dostarczonymi przez książąt mazowieckich królowi polskiemu. Przy okazji objaśniania pełnionego przez Mikołaja urzędu hetmana należy pokrótce nakreślić kontekst, który spowodował włączenie się Mazowsza w wojnę przeciwko zakonowi. W chwili wybuchu wojny trzynastoletniej na Mazowszu istniały dwa niezależne od siebie księstwa. Pierwsze z nich - płockie obejmowało ziemię płocką, rawską, gostynińską, zawkrzeńską i wiską. Drugie księstwo - warszawskie łączyło ziemię warszawską, czerską, liwską, nurską, łomżyńską, ciechanowską, różańską, zakroczymską i wyszogrodzką. Prowadziły one niezależną od siebie politykę, często jednak współpracując ze sobą. W związku z pełnieniem urzędu w ziemi gostynińskiej Mikołaj był poddanym Władysława I płockiego ${ }^{12}$. Aleksander Swieżawski w swojej pracy Mazowsze wobec wojny trzynastoletniej wskazywał na wspólną wrogość książąt mazowieckich wobec Kazimierza Jagiellończyka. Było to spowodowane wspólną rywalizacją Władysława I płockiego i Bolesława IV warszawskiego z Kazimierzem Jagiellończykiem o tron polski po śmierci Władysława Warneńczyka pod Warną. Książęta mazowieccy byli przekonani, że tron polski winien należeć wyłącznie do przedstawicieli dynastii piastowskiej. Kazimierza Jagiellończyka uważali za uzurpatora. Dlatego, na co wskazuje A. Swieżawski, Piastowie mazowieccy chętnie wiązali się z wrogami królestwa polskiego. Książęta znajdowali oparcie w rzeszach szlachty zainteresowanej czerpaniem korzyści w handlu z zakonem krzyżackim. Państwo krzyżackie było najlepszym rynkiem zbytu na produkty mazowieckie ${ }^{13}$. Nie powinno nas więc dziwić, że w początkowej fazie konfliktu książę płocki Władysław wysłał do Malborka zaciężnych na pomoc zakonowi. Działania Mazowsza spotkały się z głębokim protestem panów polskich. Z tego względu król zaczął naciskać na książąt mazowieckich, by ci wypowiedzieli wojnę zakonowi, co Władysław I uczynił ostatecznie w 1455 r., jednak dość szybko się z tego wycofał. Wpływ na to miały zapewne

11 Metryka koronna, nr 337, k. $55 \mathrm{v}$.

12 W. Sieradzan, Sąsiedztwo mazowiecko-krzyżackie. W okresie przemian politycznych w Europie Środkowo-Wschodniej w latach 1411-1466, Toruń 1999, s. 65.

13 A. Swieżawski, Mazowsze wobec wojny trzynastoletniej, ,Zeszyty Naukowe Uniwersytetu Łódzkiego. Nauki Humanistyczno-Społeczne” 1969, seria I, z. 60, s. 65-66. 
działania zaciężnych wojsk krzyżackich na obszarze pogranicznym ${ }^{14}$. Władysław zmarł w nocy z 11 na 12 grudnia 1455 r., w Niedźwiedzy, pod Sochaczewem. Wiesław Sieradzan stwierdził, że Władysław I w sprawie konfliktu na północy reprezentował zdecydowanie samodzielną i jednocześnie separatystyczną politykę. Pozostawił po sobie dwóch następców, Siemowita VI i Władysława II. Obaj książęta byli w chwili objęcia rządów małoletni, stąd też regencję nad nimi sprawowała oficjalnie ich matka, księżna Anna, córka Konrada V, księcia Oleśnickiego. Jednak faktyczną władzę na Mazowszu Płockim sprawował biskup płocki Paweł Giżycki h. Gozdawa. Jego niechętna postawa wobec związku pruskiego zmieniła się w wyniku ataków krzyżackich wojsk zaciężnych na Mazowsze. W 1457 r. mamy do czynienia z kolejnym najazdem krzyżackim na ziemie mazowieckie.

Od $1457 \mathrm{r}$. rozpoczyna się okres prowadzenia rokowań z Mazowszem w sprawie wycofania z konfliktu. Ostatecznie zawarto pokój w $1459 \mathrm{r}$. Na jego mocy książęta uzyskali m.in. prawo do udzielenia pomocy królowi polskiemu, wynikające z zobowiązań lennych Mazowsza względem Korony Polskiej ${ }^{15}$. W związku z wypełnianiem obowiązków lennych, wobozie polskim pod Chojnicami, po koncentracji z wojskami królewskimi, znalazły się wojska Piastów mazowieckich, pod dowództwem Mikołaja z Kutna (ks. Płockie) i Piotra Kłockiego (ks. Warszawskie). Niewątpliwie, na co wskazuje większość historyków, funkcja stałego hetmana nie występowała, a jedynie, jak pisze Marek Plewczyński, jednej osobie przekazywano na czas kampanii wojennej dowodzenie odziałem zbrojnym lub całym wojskiem, natomiast po zakończeniu kampanii funkcja ta ustawała ${ }^{16}$. Trochę inną analizę zagadnienia przedstawia Zdzisław Spieralski w pracy Geneza i początki hetmaństwa w Polsce:

Instytucję hetmanów omawianego okresu można zdefiniować w następujący sposób: gdy wojna jest prowadzona przy pomocy rot zaciężnych na czele tych rot staje wyznaczony przez króla hetman (campiductor), który mając pod swymi rozkazami dowódców rot (rotmistrzów) prowadzi samodzielne, bądź we współdziałaniu $\mathrm{z}$ innymi hetmanami, działania wojenne w określonym terenie [...]. Kompetencje hetmanów mają charakter ściśle operacyjny, niekiedy jednak połączone $\mathrm{z}$ uprawnieniami natury organizacyjnej, a zawsze z uprawnieniami

14 W. Sieradzan, Sąsiedztwo mazowiecko-krzyżackie..., s. 69-73, A. Swieżawski, Mazowsze..., s. 69.

15 W. Sieradzan, Sąiedztwo mazowiecko-krzyżackie..., s. 75-77.

16 M. Plewczyński, Mieszkańcy Warszawy i Mazowsza w wojnach lat 1390-1466, [w:] Z militarnych dziejów Warszawy, red. A. Ajnenkiel, Warszawa 1996, s. 31-48. 
natury dyscyplinarnej. Po wypełnieniu wyznaczonego zadania rola hetmana się kończy, przy czym nie zawsze się to zabiega w czasie z końcem samej wojny ${ }^{17}$.

Autor łączy urząd hetmana $\mathrm{z}$ wojskami zaciężnymi ${ }^{18}$. Chociaż Mazowszanie dostarczali wojsk zaciężnych obu walczącym stronom, to w tym konkretnym wypadku należy raczej wykluczyć pogląd, że Mikołaj nie dowodził wojskami zaciężnymi. Przeczy temu dokument z 9 października 1461 r., znajdujący się w metryce koronnej, wydanej przez hetmana wojsk płockich, Mikołaja z Kutna. Rozprawa dotyczy sporu pomiędzy Piotrem z Łochowa a niejakim Mikołajem Szczygłem z Wiśniczy (pierwszy z nich obraził drugiego). Sprawę jednak odłożono na czas po odbyciu wyprawy ${ }^{19}$. Kontynuowano ją 28 października 1461 r., w Gostyninie ${ }^{20}$. Według M. Plewczyńskiego, odroczenie decyzji z 9 października miało na celu przeniesienie sprawy z sądu wojskowego do sądu książęcego ${ }^{21}$. Wobec tego możemy poważnie potraktować kolejną teorię Z. Spieralskiego, który stwierdza, że niemieckie Hauptmann jest dosłownym tłumaczeniem łacińskiego capitaneus, czyli starosty. W „listach niemieckich" starostowie używali tytułu hauptmann. Między innymi Dobiesław z Kurozwęk kasztelan rozpierski, w dokumencie z 12 grudnia 1475 r., tytułuje się „hetman generalis regis poloniae”22. Jednak pełna tytulatura Mikołaja na dokumencie brzmi: „Nicolaus de Cuthno dapifer et capitanus Gostinensi et hetmanus illustrorum dominorum ducum plocensium"23. Wskazuje to raczej na oddzielny tytuł hetmana jako dowódcy pospolitego ruszenia mazowieckiego. Potwierdzenie stanowi dokument z 28 października 1461 r., w którym Mikołaj tytułowany jest jako campiductor ${ }^{24}$.

Kres karierze Mikołaja przy książętach mazowieckich przynosi śmierć dwóch Piastów, najpierw w dzień nowego roku 1462 r. Siemowita VI, a 26 lub 27 lutego Władysława II $^{25}$. Do spadku po zmarłych Piastach zgłosili się

17 Z. Spieralski, Geneza i początki hetmaństwa w Polsce, „Studia i Materiały do Historii Wojskowości” 1960, t. 5, s. 311.

18 Ibidem.

19 Metryka koronna, nr 337, k. 53 v; A. Wolff, Studia nad urzędnikami mazowieckimi 1370-1526, Wrocław 1962, s. 82-83.

20 Metryka koronna, nr 337, k. 53 v.

21 M. Plewczyński, Mieszkańcy Warszawy i Mazowsza..., s. 44.

22 Z. Spieralski, Geneza..., s. 337.

23 Metryka koronna, nr 337, $53 \mathrm{v}$.

24 Ibidem.

25 A. Swieżawski, Wcielenie ziemi rawskiej, gostynińskiej i bełskiej do korony (1462), "Zeszyty Naukowe Uniwersytetu Łódzkiego. Nauki Humanistyczno-Społeczne” 1962, seria I, z. 27, s. 36. 
liczni pretendenci ${ }^{26}$. Faktyczną władzę w ziemi rawskiej i gostynińskiej sprawowali starostowie tamtejszych zamków, Mikołaj z Kutna w Gostyninie i Jan Grot z Nowego Miasta w Rawie. Reprezentowali oni niewątpliwie interesy szlachty lokalnej, która zdecydowała się opowiedzieć po stronie króla polskiego. Kazimierz Jagiellończyk od dłuższego czasu nosił się z zamiarem opanowania księstw mazowieckich, jednak brakowało mu sił zbrojnych, gdyż większość wojsk zaangażowana była w trwającej nadal wojnie trzynastoletniej. Wobec tego w opanowaniu księstw mazowieckich król mógł liczyć tylko i wyłącznie na przychylność tamtejszej szlachty ${ }^{27}$. Kazimierz Jagiellończyk uważał, że po śmierci książąt, którzy byli jego lennikami, ich ziemie powinny przypaść Polsce ${ }^{28}$. Ze wszystkich pretendentów najszybciej zareagowała księżna Katarzyna, która w chwili śmierci księcia Władysława znajdowała się, według A. Swieżawskiego, w Płocku lub w Płońsku. Jako pierwsza objęła władzę na ziemiach położonych na prawym brzegu Wisły. Ciekawostkę może stanowić fakt, że Jan z Kutna, ojciec Mikołaja, opowiedział się całkowicie po stronie księżnej Katarzyny ${ }^{29}$. Księżna płocka podjęła próbę opanowania zamku rawskiego, ale wobec oporu Jana Grota i protestów królewskich odstąpiła od tego przedsięwzięcia ${ }^{30}$. O przyłączeniu ziemi rawskiej i gostynińskiej do Korony pisał Jan Długosz:

Król Kazimierz wyjechawszy w sobotę, w dzień świętej Barbary z Piotrkowa, udał się w asyście arcybiskupa gnieźnieńskiego Jana i biskupa włocławskiego Jana oraz wielu rycerzy do grodów Rawa i Gostynina, które dla niego były trzymane. A przybywszy w dzień świętego Mikołaja do Rawy ${ }^{31}$ przyjął przekazany mu w posiadanie przez cześnika Grota gród Rawę, a potem

26 Piastowie wschodniomazowieccy - Konrad III, Kazimierz II, Bolesław V i Janusz II - byli niepełnoletni, a w obronie ich praw do tronu wystąpiła ich matka, ks. Barbara. Prócz nich Wacław I bytomski i Przemysł II, książę cieszyński i głogowski, jako synowie Ofki, córki Siemowita, Katarzyna, córka Siemowita V, wdowa po Michale Zygmuntowiczu oraz Małgorzata, też córka Siemowita V, księżna oleśnicka. A. Swieżawski, Spór o sukcesję mazowiecka 1462-1468, „Zeszyty Naukowe Uniwersytetu Łódzkiego. Nauki Humanistyczne” 1970, seria I, z. 72, s. 19-34.

27 A. Swieżawski, Wcielenie ziemi rawskiej..., s. 38, 41.

28 Ibidem, s. 38

29 A. Swieżawski, Rawskie księstwo Piastów Mazowieckich 1313-1462. Dzieje polityczne, Łódź 1975, s. 162-163.

30 H. Samsonowicz, Dzieje polityczne (połowa XIV-początek XVI w.), [w:] Dzieje Mazowsza do 1526 r., red. A. Gieysztor, H. Samsonowicz, Warszawa 1994, s. 227.

316 grudnia $1462 \mathrm{r}$. 
kiedy posuwał się do Gostynina, przekazany mu w posiadanie przez Mikołaja Kuczeńskiego Gostynin ${ }^{32}$. Przyjął też od rycerzy jednego i drugiego okręgu przysięgę wierności. Wynagrodziwszy zaś wierność cześnika Grota i Mikołaja Kuczeńskiego wieczystym nadaniem pewnych wsi, także te zamki, które mu przekazali, daje im dożywotnio w dzierżawę $e^{33}$.

W dokumencie królewskim z 17 grudnia 1462 r., wystawionym w Gostyninie, dotyczącym inkorporacji ziemi gostynińskiej do Korony Mikołaj z Kutna występuje z tytułami „dapifero et capitaneo gostynensi”34. Należy wspomnieć, że na dokumencie Kazimierza Jagiellończyka z 20 grudnia 1462 r., wydanym w Gostyninie, mocą którego król polski inkorporował miasto Gostynin do królestwa, występuje ojciec Mikołaja Jan z Kutna, dotychczasowy stronnik księżnej Katarzyny płockiej ${ }^{35}$.

Niewątpliwie problem wcielenia ziemi gostynińskiej do korony będzie się ciągnął jeszcze do 1468 r. Książęta mazowieccy do swojego wymarcia będą się tytułować panami Rawy i Gostynina, także w większości dokumentów z lat 1465-1468. Mikołaj z Kutna występował jako bezpośredni świadek kolejnych dokumentów. Należy zwrócić uwagę, że od 1467 r. funkcjonuje jako wojewoda łęczycki. Niniejszy artykuł należy potraktować jako przyczynek do szerokiej działalności politycznej Mikołaja z Kutna.

\section{Bibliografia}

\section{Źródła}

DŁUGOSZ J., Roczniki czyli kroniki Sławnego Królestwa Polskiego, ks. XII, tłum. J. Mrukówna, Warszawa 2009.

Iura masoviae terrestria. Pomniki dawnego prawa mazowieckiego, t. 1, red. J. Sawicki, Warszawa 1972.

Metryka księstwa Mazowieckiego, ks. 337 [AGAD w Warszawie].

Zbiór dokumentów Małopolskich, t. 8, red. I. Sułkowska-Kuraś, S. Kuraś, Wrocław 1975.

\footnotetext{
4 grudnia $1462 \mathrm{r}$.

33 J. Długosz, Roczniki czyli kroniki Sławnego Królestwa Polskiego, ks. XII, Warszawa 2009, s. 57-58.

34 Iura masoviae terrestria. Pomniki dawnego prawa mazowieckiego [dalej IMT], t. 1, dok. nr 112, red. J. Sawicki, Warszawa 1972, s. 209-212.

35 IMT, dok. nr 113, s. 212-214.
} 
Jakub Parol

\section{Opracowania}

GĄSIOROWSKI A., Kucieński Mikołaj, [w:] Polski słownik biograficzny, t. 16, red. E. Rostworowski, Wrocław-Warszawa-Kraków 1971.

NOWAK T., Kutno i Łąkoszyn do schyłku XVI wieku, [w:] Kutno poprzez wieki, red. J. Szymczak, Łódź-Kutno 2011, s. 131-160.

NOWAK T., Własność ziemska w Ziemi Łęczyckiej w czasach Władysława Jagiełty, Łódź 2003.

PACUSKI K., Możnowładztwo i rycerstwo ziemi gostynińskiej w XIV i XV wieku. Studium z dziejów osadnictwa i elity władzy na Mazowszu średniowiecznym, Warszawa 2009.

PLEWCZYŃSKI M., Mieszkańcy Warszawy i Mazowsza w wojnach lat 13901466, [w:] Z militarnych dziejów Warszawy, red. A. Ajnenkiel, Warszawa 1999.

ROSIN R., Kutno i okoliczne miejscowości do połowy XVI w., [w:] Kutno - dzieje miasta, red. R. Rosin, Warszawa-Łódź 1984, s. 19-48.

SAMSONOWICZ H., Dzieje polityczne (połowa XIV - początek XVI w.), [w:] Dzieje Mazowsza do 1526, red. A. Gieysztor, H. Samsonowicz, Warszawa 1994, s. 213-248.

SIERADZAN W., Sąsiedztwo mazowiecko-krzyżackie. W okresie przemian politycznych w Europie Środkowo-Wschodniej w latach 1411-1466, Toruń 1999.

SPIERALSKI Z., Geneza i początki hetmaństwa w Polsce, „Studia i Materiały do Historii Wojskowości” 1960, t. 5, s. 295-348.

SWIEŻAWSKI A., Spór o sukcesję Mazowiecka 1462-1468, „Zeszyty Naukowe Uniwersytetu Łódzkiego. Nauki Humanistyczne” 1970, seria I, z. 72, s. 1934.

SWIEŻAWSKI A., Wcielenie ziemi rawskiej, gostynińskiej i bełskiej do korony (1462), „Zeszyty Naukowe Uniwersytetu Łódzkiego. Nauki Humanistyczno-Społeczne” 1962, seria I, z. 27, s. 35-45.

WOLFF A., Studia nad urzędnikami Mazowieckimi 1370-1526, Wrocław 1962. 